\title{
Detection of p53 in inflammatory tissue and lymphocytes using immunohistology and flow cytometry: a critical comment
}

\author{
A Nickels, H Selter, M Pfreundschuh, M Montenarh, B Koch
}

\begin{abstract}
Aims-To analyse the expression of p53 in lymphatic cells found in inflammatory tissues and the peripheral blood by immunological methods.

Methods-Immunohistological analysis of synovial tissues from patients with rheumatoid arthritis and flow cytometric analysis of peripheral blood lymphocytes were performed with anti-p53 antibodies from different sources.
\end{abstract}

Results-The anti-p53 antibodies PAb240, PAb421, and PAb1801 from one supplier bound to the cytoplasm of lymphocytes, fibroblasts, and endothelial cells in rheumatoid synovial tissue, while the same anti-p53 antibodies from other sources and the p53 specific antibodies PAb1620 and DO1 were negative. Using flow cytometry, the antibodies that labelled cells in inflammatory tissues were shown to bind also to peripheral lymphocytes, while the antibodies that were negative in immunohistology did not react with peripheral blood lymphocytes. p53 expression could be confirmed by western blot in rheumatoid synovial tissue, but not in peripheral blood lymphocytes using PAb421 and PAb240 antibodies from our own laboratory, which had been negative in immunohistology.

Conclusions-Demonstration of p53 by western blot is more sensitive and reliable than immunohistology and flow cytometry. Western blot is the gold standard for the demonstration of p53 expression and should be used, whenever possible, to confirm p53 expression in normal tissue shown by immunohistology or flow cytometry. All other reports on p53 expression, especially those obtained using antibodies with an unusual staining pattern must be interpreted with caution. (F Clin Pathol 1997;50:654-660)

Keywords: p53; rheumatoid arthritis; immunological detection

\section{Department of}

$M$ Pfreundschuh

B Koch

Correspondence to: Dr Koch, Department of Internal Medicine I, University of the Saarland, D-66421 Homburg, Germany.

Accepted for publication 13 May 1997 mutation is a common event in the development of human malignancies that occurs in $>50 \%$ of all human tumours. ${ }^{3}$ p53 is located mainly in the nucleus, although cytoplasmic and nucleolar localisation of p53 have been reported. ${ }^{4-6}$ Immunohistochemical analysis revealed that p53 is overexpressed in many tumour cells and after DNA damage or cellular stress in normal cells. ${ }^{7-9}$ Overexpression of p53 is due to a stabilisation of the protein rather than increased transcription. In normal nontransformed cells p53 is hardly detectable by immunohistochemical methods because of the short half-life of the protein. However, the presence of the $\mathrm{p} 53$ protein and of $\mathrm{p} 53 \mathrm{mRNA}$ has been demonstrated in activated lymphocytes, while no protein has been detected in quiescent cells using the anti-p53 antibody DO1. ${ }^{1011}$

Using immunohistological methods, $\mathrm{p} 53$ has been demonstrated in normal lymphoid tissue (antibody PAb248), ${ }^{12}$ in proliferating reactive lymphoid tissue (antibodies PAb1801 and DO7), ${ }^{13-15}$ in smooth muscle cells of coronary restenosis (antibody PAb1801), ${ }^{16}$ in chronic atrophic gastritis with intestinal metaplasia (antibody DO7), ${ }^{17}$ in normal skin (antibodies PAb122, PAb240, PAb421, and PAb1801), ${ }^{18}$ and in skin following damage such as UV radiation (antibodies DO1 and CM1). ${ }^{20}$ Using immunocytology, p53 has been demonstrated in Epstein-Barr virus infected B cells (antibody DO7) ${ }^{21}$; by flow cytometry in CD34 positive haemopoietic cells (antibodies PAb240 and PAb1801) ${ }^{22}$; and by immunoprecipitation in aging fibroblasts (antibodies PAb122 and PAb1801). ${ }^{23}$ In fibroblasts wild-type p53 was shown to exert a regulatory effect on angiogenesis. ${ }^{24}$

Rheumatoid arthritis is characterised by an inflammatory reaction in the synovial membrane of the joint. The synovial membrane is composed of a broadened layer of synovial lining cells, which contain raised numbers of lymphocytes and monocytes, and shows increased angiogenesis. ${ }^{25-27}$ Proliferating cells are present mainly near blood vessels in the lymphoid infiltrate, and in the synovial infiltrate, while resting cells are found in the intimal cell layer. ${ }^{28}$ Moreover, the presence of apoptotic cells has been demonstrated by in situ end labelling. ${ }^{29}$ Thus, tissue from patients with rheumatoid arthritis contains proliferating and nonproliferating cells, activated lymphocytes, and endothelial cells as well as apoptotic cells. As p53 is known to be involved in cell proliferation and activation, as well as apoptosis, the question arose as to whether p53 can be detected in rheumatoid synovial tissue and whether it is expressed by defined cell populations found in this tissue. Using different anti- 
p53 antibodies, we obtained conflicting results: some antibodies stained infiltrating and endothelial cells in the synovial tissue, while others failed to present this binding pattern. However, two antibodies that failed to detect p53 in rheumatoid tissue by immunohistochemical analysis detected $\mathrm{p} 53$ by western blot analysis. The results are discussed with regard to the previously published binding pattern of p53 specific antibodies.

\section{Methods}

PATIENTS AND CONTROLS

Synovial tissues were obtained from nine patients with rheumatoid arthritis during therapeutic synovectomy. Peripheral blood cells were obtained, after written informed consent, from three healthy controls, and from one patient each with chronic lymphocytic leukaemia of the T cell type (T-CLL) and of the B cell type (B-CLL). The study was approved by the local ethics committee (Ethikkommission der Ärztekammer des Saarlandes).

SAMPLING OF THE TISSUES AND CELLS

Synovial tissues were snap frozen in liquid nitrogen and stored at $-70^{\circ} \mathrm{C}$. Heparinised peripheral blood was diluted $1 / 2$ with phosphate buffered saline (PBS), and mononuclear cells were isolated by ficoll density gradient centrifugation at $400 \times g$ for 20 minutes. Mononuclear cells were washed twice with PBS, resuspended at $2 \times 10^{6}$ cells $/ \mathrm{ml}$, and fixed with $4 \%$ (vol $/ \mathrm{vol}$ ) formaldehyde in PBS for 20 minutes. Fixed cells were washed twice with PBS and stored in PBS containing $0.5 \%$ bovine serum albumin (BSA) and $0.01 \% \mathrm{NaN}_{3}$ (BSA buffer) at a concentration of $10^{6}$ cells $/ \mathrm{ml}$.

ANTIBODIES AND REAGENTS

The monoclonal p53 specific antibodies $\mathrm{PAb} 240$ were obtained from Oncogene Science (Uniondale, USA; PAb240-1, lot number 86900125), from Boehringer Mannheim (Mannheim, Germany; PAb240-2), and from our own laboratory (PAb240-3). PAb421 antibodies were obtained from Oncogene Science (PAb421-1, lot number 39930104; PAb421-2, lot number 44920112) and from our own laboratory (PAb421-3). The PAb1620 antibody came from our own laboratory, PAb1801 from Oncogene Science (PAb1801-1, lot number 45930108), and from LOXO (Dossenheim, Germany; PAb1801-2), and the DO1 antibody from Oncogene Science. The isotype matched monoclonal $\mathrm{IgG}_{1}$ and $\mathrm{IgG}_{2}$ control antibodies, the antifibroblast antibody, the polyclonal antibody rabbit antimouse IgG, and the alkaline phosphatase anti-alkaline phosphatase (APAAP) complex were obtained from Dako (Hamburg, Germany). The polyclonal goat antimouse IgG, conjugated to fluorescein or to lissamine rhodamine (LR) or unconjugated, each as $F(a b)$ fragments, were obtained from Oncogene Science. The phycoerythrin (PE) conjugated monoclonal antibodies antiCD3, anti-CD4, anti-CD8, and anti-CD19 were obtained from Becton Dickinson (Heidelberg, Germany). Saponin (from quillaja bark), BSA, naphthol AS-BI phosphate, new fuchsin, and haematoxylin were obtained from Sigma (Deisenhofen, Germany); formaldehyde from Merck (Darmstadt, Germany); rabbit serum and goat serum from Dako (Hamburg, Germany); and fetal calf serum (FCS) from Life Technologies (Eggenstein, Germany).

\section{IMMUNOHISTOCHEMISTRY AND}

IMMUNOFLUORESCENCE ANALYSIS

Cryostat sections $(6 \mu \mathrm{m})$ from synovial tissues were air dried for 24 hours at room temperature, then fixed in acetone for 10 minutes. The immunohistological investigations were performed in a moist chamber at room temperature. For immunohistochemistry, p53 specific antibodies and the isotype control antibodies were applied at a concentration of $10 \mu \mathrm{g} / \mathrm{ml}$, rabbit and goat antimouse antibodies (unconjugated and as fluorescein or LR conjugates) at a concentration of $50 \mu \mathrm{g} / \mathrm{ml}$, and the APAAP complex diluted $1 / 40$ in $5 \%$ FCS. The anti-CD3 PE, anti-CD4 PE, anti-CD8 PE, anti-CD19 PE conjugates, and the antifibroblast antibody reacting with the $\beta$ subunit of prolyl-4-hydroxylase were used at a concentration of $5 \mu \mathrm{g} / \mathrm{ml}$.

The slides were covered with $5 \%(\mathrm{vol} / \mathrm{vol})$ rabbit serum, diluted with Tris buffered saline (TBS), incubated with the p53 specific antibody for 20 minutes, washed twice with TBS, incubated with the rabbit antimouse IgG antibody for 30 minutes, washed twice with TBS, and then incubated with the APAAP complex for 30 minutes. To increase the sensitivity of the test, the incubation with the antimouse antibody and with the APAAP complex was repeated once. As substrate for the alkaline phosphatase we used naphthol AS-BI phosphate and new fuchsin. The counterstaining was performed with haematoxylin. Incubation with unrelated $\operatorname{IgG}_{1}$ and $\operatorname{IgG}_{2}$ antibodies was used as control. The microscopical analysis was performed with a Zeiss microscope (Zeiss, Oberkochen, Germany).

\section{DOUBLE IMMUNOFLUORESCENCE}

Following incubation with $5 \%$ (vol $/ \mathrm{vol}$ ) goat serum (diluted with TBS) for 15 minutes, the slides were incubated with the p53 specific antibodies, washed twice with TBS, incubated with the fluorescein labelled goat antimouse IgG $F(a b)$ fragment, ${ }^{30}$ and saturated with the unconjugated antimouse IgG $\mathrm{F}(\mathrm{ab})$ fragment; the slides were then incubated with anti-CD3 PE, anti-CD4 PE, anti-CD8 PE, and antiCD19 PE. The binding of the antifibroblast antibody was detected by an LR labelled antimouse IgG. The analysis of the slides was performed with a Zeiss fluorescence microscope.

\section{FLOW CYTOMETRY}

For the analysis of p53 by flow cytometry we applied the saponin permeabilisation procedure. ${ }^{31}$ Antibodies were used in the same concentration as for immunohistology; however, anti-p53 antibodies and antimouse IgG antibodies were diluted in BSA buffer containing $0.5 \%$ saponin. Following fixation with $4 \%$ (vol/vol) formaldehyde the mononuclear cells were washed with saponin/BSA buffer, incu- 
Table 1 Binding of the p53 antibodies PAb240 (-1, -2, -3), PAb421 (-1, -2, -3), PAb1620, PAb1801 ( $-1,-2)$, and DO1 to synovial tissue from patients with rheumatoid arthritis

\begin{tabular}{|c|c|c|c|c|c|c|c|c|c|c|}
\hline & \multicolumn{3}{|c|}{$P A b 240$} & \multicolumn{3}{|c|}{$P A b 421$} & \multirow{2}{*}{$\begin{array}{l}P A b \\
1620\end{array}$} & \multicolumn{2}{|c|}{ PAb1801 } & \multirow[b]{2}{*}{ DO1 } \\
\hline & -1 & -2 & -3 & -1 & -2 & -3 & & -1 & -2 & \\
\hline \multirow{2}{*}{\multicolumn{11}{|c|}{$\begin{array}{l}\text { Synoviocyte layer } \\
\text { Cells in the }\end{array}$}} \\
\hline & & & & & & & & & $0 / 2$ & $0 / 6$ \\
\hline Endothelial cells & $9 / 9$ & $0 / 2$ & $0 / 3$ & $0 / 9$ & $0 / 3$ & $0 / 3$ & $0 / 5$ & $0 / 9$ & $0 / 2$ & $0 / 6$ \\
\hline Perivascular cells & $9 / 9$ & $0 / 2$ & $0 / 3$ & $9 / 9$ & $0 / 3$ & $0 / 3$ & $0 / 5$ & $1 / 9$ & $0 / 2$ & $0 / 6$ \\
\hline \multicolumn{11}{|l|}{ Lymphoid } \\
\hline aggregates & $9 / 9$ & $0 / 2$ & $0 / 3$ & $8 / 9$ & $0 / 3$ & $0 / 3$ & $0 / 5$ & $6 / 9$ & $0 / 2$ & $0 / 6$ \\
\hline
\end{tabular}

Values are number of positive areas/number of analysed areas.

bated with p53 specific antibodies for $30 \mathrm{~min}$ utes, washed twice with saponin/BSA buffer, incubated with a fluorescein labelled goat antimouse IgG F(ab) fragment, washed once with saponin/BSA buffer and once with PBS, and incubated with anti-CD3 PE or anti-CD19 PE for 30 minutes. The FACScan analysis was performed with the LYSYS II software program (Becton Dickinson).

\section{WESTERN BLOT ANALYSIS}

For the analysis of synovial tissues by western blot, tissues and mononuclear cells were disrupted mechanically and incubated with extraction buffer (100 mM Tris $\mathrm{HCl}, \mathrm{pH} 9.0$, $100 \mathrm{mM} \mathrm{NaCl}, 0.5 \% \mathrm{NP} 40$ ) for one hour at $4^{\circ} \mathrm{C}$. After sonification the mixture was centrifuged at $95000 \times g$ for 30 minutes. The supernatants were dialysed against $50 \mathrm{mM}$ $\mathrm{NH}_{4} \mathrm{HCO}_{3}$ and subsequently lyophilised. Sample buffer $(65 \mathrm{mM}$ Tris $\mathrm{HCl}, \mathrm{pH} 6.8,10 \%$ glycerol, $5 \%$ 2-mercaptoethanol, $2 \%$ sodium dodecyl sulphate (SDS), $0.01 \%$ bromophenol blue) was added and the probes were boiled for 10 minutes. Solubilised proteins were separated by SDS-polyacrylamide gel electrophoresis (PAGE) and blotted on to nitrocellulose membranes. After blocking the membranes with buffer A (blocking buffer: PBS containing $5 \%$ (wt/vol) milk powder (Nestle, Frankfurt, Germany) and $0.2 \%$ Tween 20 (Fluka, Buchs, Switzerland)) for one hour, the primary antibodies PAb421-3 or PAb240-3 were added at a 1/500 dilution (diluted in blocking buffer), followed by incubation with a pre-absorbed goat antimouse peroxidase conjugated antibody for one hour (Dianova, Hamburg, Germany). For visualisation, the ECL-Kit (enhanced chemiluminescence reagents; Amersham, Little Chalfont, UK) was used. As a control for crossreactivity of the secondary antibody, a separate nitrocellulose membrane was incubated with the pre-absorbed goat antimouse peroxidase conjugated antibody (Dianova).

\section{Results}

BINDING OF P53 SPECIFIC ANTIBODIES TO

RHEUMATOID SYNOVIAL TISSUE

For the immunohistological detection of p53 in rheumatoid synovial tissue we used antibodies directed against different epitopes of the p53 molecule. These included different lot numbers and sources of the anti-p53 mouse monoclonal antibody PAb240 (which recognises a conformation dependent epitope specifically exposed in the majority of p53 mutant proteins and reacts with wild-type p53), ${ }^{32}{ }^{33}$ of PAb421 (which is known to react with both wild-type and mutant p53), ${ }^{34}$ and of PAb1801 (which recognises a human p53 specific epitope on wild-type and mutant p53). ${ }^{35}$ All batches of all p53 specific antibodies were shown to react with recombinant $\mathrm{p} 53$ by western blot analysis and were used in the titres as suggested by the distributors or after titration in our laboratory.

In synovial tissues several areas were evaluated, especially the synoviocyte layer, the inflamed subsynovial tissue, endothelial cells, perivascularly located cells, and cells in lymphoid aggregates. PAb240-1 reacted with cells in the subsynovial tissue, perivascularly located cells, endothelial cells, and cells in lymphoid aggregates in all cases examined; in addition it reacted with cells of the synoviocyte layer in eight of nine cases. In all cases, PAb421-1 bound to perivascularly located cells, in eight of nine cases to cells in lymphoid aggregates, and in three of nine cases to cells in the subsynovial tissue. PAb1801-1 stained cells in lymphoid aggregates in six of nine cases and cells in the synoviocyte layer, the subsynovial tissue, and perivascularly located cells in one case (table $1)$.

To confirm these observations we repeated the experiments with different lot numbers of a given antibody from one supplier or defined antibodies from different suppliers with the result that antibodies PAb240-2, PAb240-3, PAb421-2, PAb421-3, and PAb1801-2 were negative. Moreover, two other monoclonal antibodies, PAb1620 and DO1, were negative on synovial tissue (table 1). PAb1620 is known to bind specifically to the wild-type conformation of $\mathrm{p} 53^{36}{ }^{37}$ and DO1 is a mouse monoclonal antibody that recognises an epitope near the $\mathrm{N}$-terminus of the human $\mathrm{p} 53$ protein. ${ }^{38}$ These results indicate that p53 may be detected immunohistologically by the application of certain p53 specific antibodies in various compartments of the rheumatoid synovial tissue, and that the staining pattern with different p53 specific antibodies may differ considerably.

CHARACTERISATION OF PAB421-1 BINDING CELLS As we had found that perivascularly located cells and cells with round nuclei in the subsynovial tissue reacted with the antibody PAb421-1, we further characterised these cells for reactivity with anti-CD3, anti-CD4, antiCD8, and anti-CD19 antibodies. In all cases $(\mathrm{n}=7) \mathrm{PAb} 421-1^{+}$cells were identified as $\mathrm{T}$ cells (fig 1$)^{1}$, in four cases as $\mathrm{CD} 4^{+}$, and in three cases as $\mathrm{CD}^{+} \mathrm{T}$ cells. PAb421-1 ${ }^{+}$cells did not react with antibodies specific for B cells (CD19) or fibroblasts, confirming that PAb421-1 ${ }^{+}$cells were exclusively $\mathrm{T}$ cells (table 2 ).

BINDING OF P53 SPECIFIC ANTIBODIES TO CELLS OF THE PERIPHERAL BLOOD

The binding of PAb421-1 to T cells in inflammatory tissues raised the question as to whether the respective anti-p53 antibodies bind also to peripheral blood lymphocytes. For the detection of intracellular antigens of cells in 

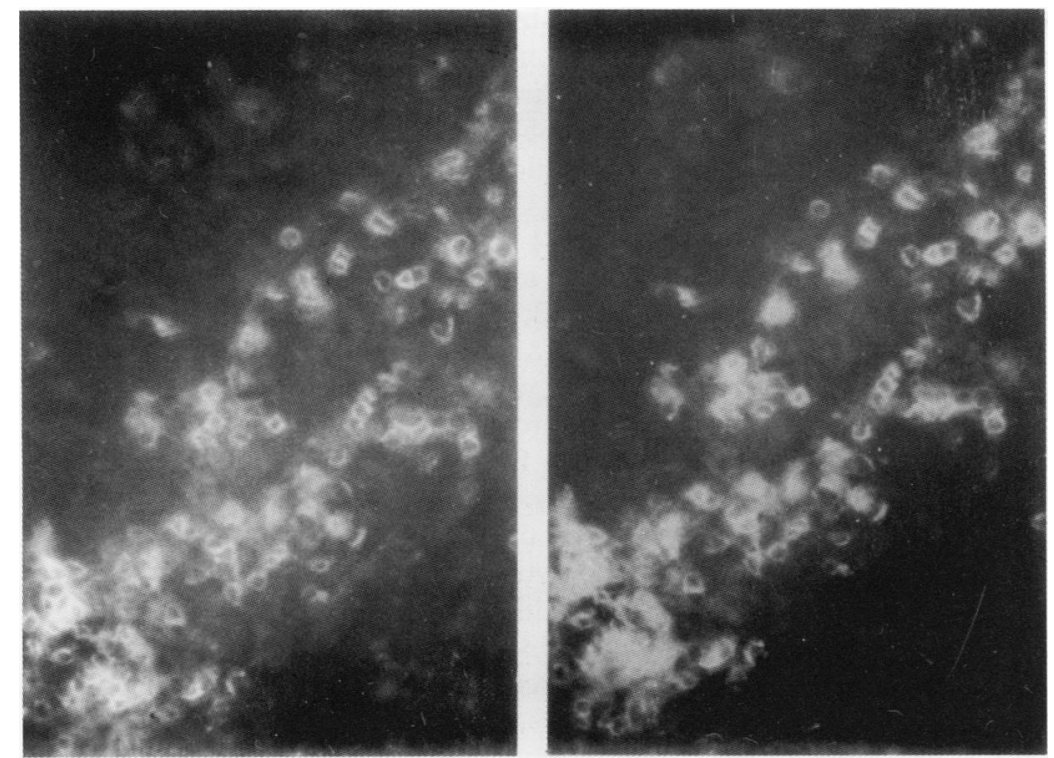

Figure 1 The presence of lymphocytes in rheumatoid synovial tissue that bind simultaneously the anti-p53 antibody, PAb421-1, and anti-CD3. Staining with PAb421-1 (left); staining with anti-CD3 (right). (Original magnification $\times 400$.)

Table 2 Characterisation of the PAb421-1 binding cells in rheumatoid synovial tissues by a double flourescence technique with antibodies against lymphocyte subpopulations and fibroblasts

\begin{tabular}{llllll}
\hline Tissue & Anti-CD3 & Anti-CD4 & Anti-CD8 & Anti-CD19 & Anti-FB \\
\hline 1 & + & - & + & - & - \\
2 & + & + & + & - & - \\
3 & + & - & - & - & - \\
4 & + & ND & - & - & ND \\
5 & + & + & - & - & - \\
6 & + & + & + & - & - \\
7 & + & & + & &
\end{tabular}

Presence (+) and absence ( - ) of double labelled cells. $\mathrm{ND}$, not done; FB, fibroblast. ments using the anti-CD3 antibody. PAb240-1, PAb421-1, and PAb1801-1 reacted with $\mathrm{CD}^{+} \mathrm{T}$ cells of a healthy control (fig 3 ), while PAb240-2, PAb240-3, PAb421-2, PAb421-3, PAb1620, PAb1801-2, and DO1 did not label lymphocytes.

After the demonstration that PAb240-1, PAb421-1, and PAb1801-1 bound to normal T lymphocytes it became of interest to investigate the reactivity of these antibodies with malignant cells of lymphoid origin such as those from patients with T-CLL and B-CLL. We found that PAb240-1, PAb421-1, and PAb1801-1 reacted with $\mathrm{CD}^{+}{ }^{+}$T-CLL cells, while PAb1801-1 reacted with $\mathrm{CD} 19^{+} \mathrm{B}-\mathrm{CLL}$ cells (fig 3). PAb240-2, PAb240-3, PAb421-2, PAb421-3, PAb1620, PAb1801-2, and DO1 did not label T-CLL or B-CLL cells.

Thus, the results obtained with normal and malignant peripheral blood lymphocytes were in agreement with the finding in rheumatoid synovial tissues: antibodies PAb240-1, PAb421-1, and PAb1801-1 reacted with lymphocytes, while antibodies PAb240-2, PAb240-3, PAb421-2, PAb421-3, PAb1620, PAb1801-2, and DO1 did not.

\section{WESTERN BLOT ANALYSIS OF RHEUMATOID}

SYNOVIAL TISSUE

Because of the conflicting immunohistological results obtained with different batches of p53 specific antibodies we were interested as to whether p 53 could be detected in extracts from rheumatoid synovial tissues by western blotting. We extracted proteins from different rheumatoid synovial tissues that had been positive by immunohistology. A $53 \mathrm{kDa}$ protein band was demonstrated in the western blot with the monoclonal antibodies PAb421-3 and PAb240-3, confirming that p53 was expressed in these synovial tissues. The same $53 \mathrm{kDa}$ protein band appeared in the western blot of p53 expressing SV80 cells, but not when p53 negative SAOS 2 cells were used (fig 4). No 53 $\mathrm{kDa}$ protein band could be demonstrated by western blot analysis of unstimulated mononuclear cells.

P53 IN RHEUMATOID SYNOVIAL TISSUE AND PERIPHERAL BLOOD LYMPHOCYTES

In summary, with the application of different p53 specific antibodies in immunohistology and in flow cytometry we found that some antibodies such as PAb240-1, PAb421-1, and PAb1801-1 reacted with lymphocytes both in the tissue and in the peripheral blood, while other p53 specific antibodies such as PAb240-2, PAb240-3, PAb421-2, PAb421-3, PAb1620, PAb1801-2, and DO1 did not show this reactivity. Western blot analysis revealed clearly the presence of p53 in rheumatoid synovial tissue as detected by PAb421-3 and PAb240-3 (table 3).

\section{Discussion}

Previously, under certain circumstances, several types of non-malignant cells such as lymphocytes and fibroblasts have been shown to express elevated levels of the growth suppressor protein p53. ${ }^{101423}$ In this study, the

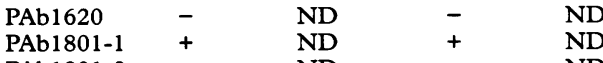

$\begin{array}{lllll}\text { PAb1801-2 } & + & \text { ND } & + & \text { ND } \\ \text { DO } & - & \text { ND } & - & \text { ND }\end{array}$

IH, immunohistology; WB, western blot; FC, flow cytometry ND, not done. 
expression of $\mathrm{p} 53$ in rheumatoid synovial tissue was demonstrated by western blot analysis. However, conflicting results were obtained when we tried to ascribe the expression of p53 to a defined cell population within the rheumatoid synovial tissue. While staining was observed with a few p53 specific antibodies, the majority of the anti-p53 antibodies used in this study were negative.

Immunohistochemical analysis of p53 was performed with a variety of monoclonal antibodies directed against p53, with different lot numbers and from different sources. The possibility that the fixation process might have contributed to false negative results was excluded by using frozen sections from synovial tissues. We found that antibodies PAb240-1, PAb421-1, and PAb1801-1 (all from the same supplier) bound to an antigen expressed in lymphocytes in synovial tissues. A double marker analysis with monoclonal antibodies directed against mononuclear cell subpopulations showed that PAb421-1 $1^{+}$cells were T lymphocytes of both the $\mathrm{CD}^{+}$and $\mathrm{CD}^{+}$ subtypes. Reactivity of p53 in T lymphocytes with some antibodies, but not with others, may be caused by the presence of different p53 species, since it has been shown that non-dividing and dividing lymphocytes express different forms of p53 that can be detected by different p53 specific antibodies. ${ }^{10} 39$ However, results obtained with PAb240-1, PAb421-1, PAb1801-1 could not be confirmed with the identical antibodies from other suppliers (PAb240-2, PAb240-3, PAb421-3 and PAb1801-2), nor with PAb1620 or DO1. In addition, we observed inconsistent results using different lot numbers of two p53 specific antibodies from one supplier (PAb421-1 and PAb421-2).

The binding of $\mathrm{p} 53$ specific antibodies to haemopoietic cells has been described several times by different groups. In several of these reports, $\mathrm{p} 53$ specific antibodies from one of our sources were used to demonstrate p53 in lymphomas, ${ }^{40-43}$ phytohaemagglutinin stimulated lymphocytes, ${ }^{14} \mathrm{CD} 34^{+}$cells from normal donors, and cells from patients with chronic myeloid leukaemia. ${ }^{22}$ In addition, p53 has been reported in other non-malignant cells such as the smooth muscle cells of coronary restenosis $^{44}$ and cells found in the pancreatic
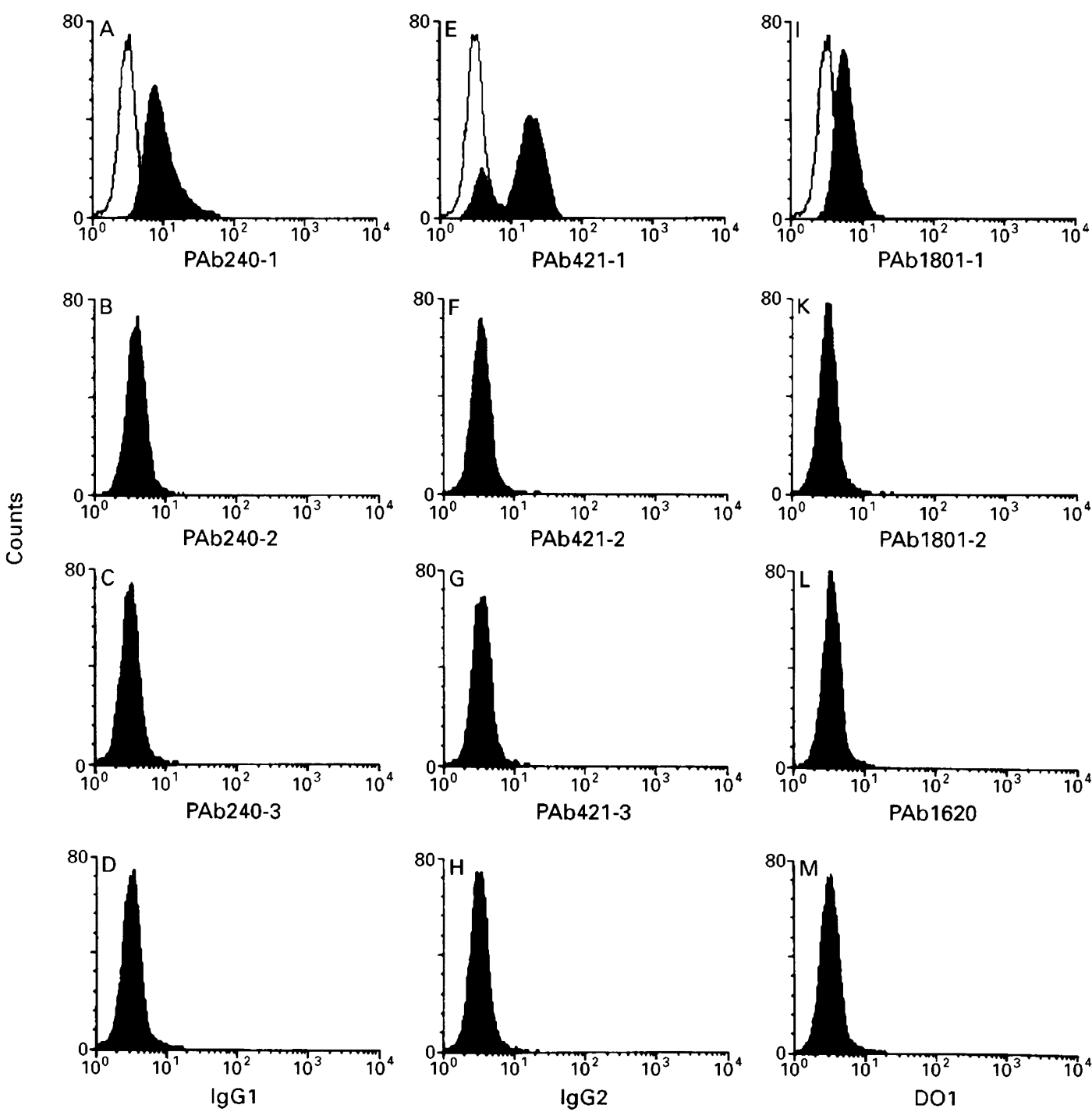

Relative fluorescence intensity

Figure 2 Binding of $p 53$ antibodies to peripheral blood lymphocytes. The anti-p53 antibodies PAb240-1, PAb421-1, and PAb1801-1 bound to lymphocytes, while the anti-p53 antibodies PAb240-2, PAb240-3, PAb421-2, PAb421-3, PAb1620, $P A b 1801-2$, and DOI did not. In panels $A, E$, and I the isotype control antibodies are shown in the background. 

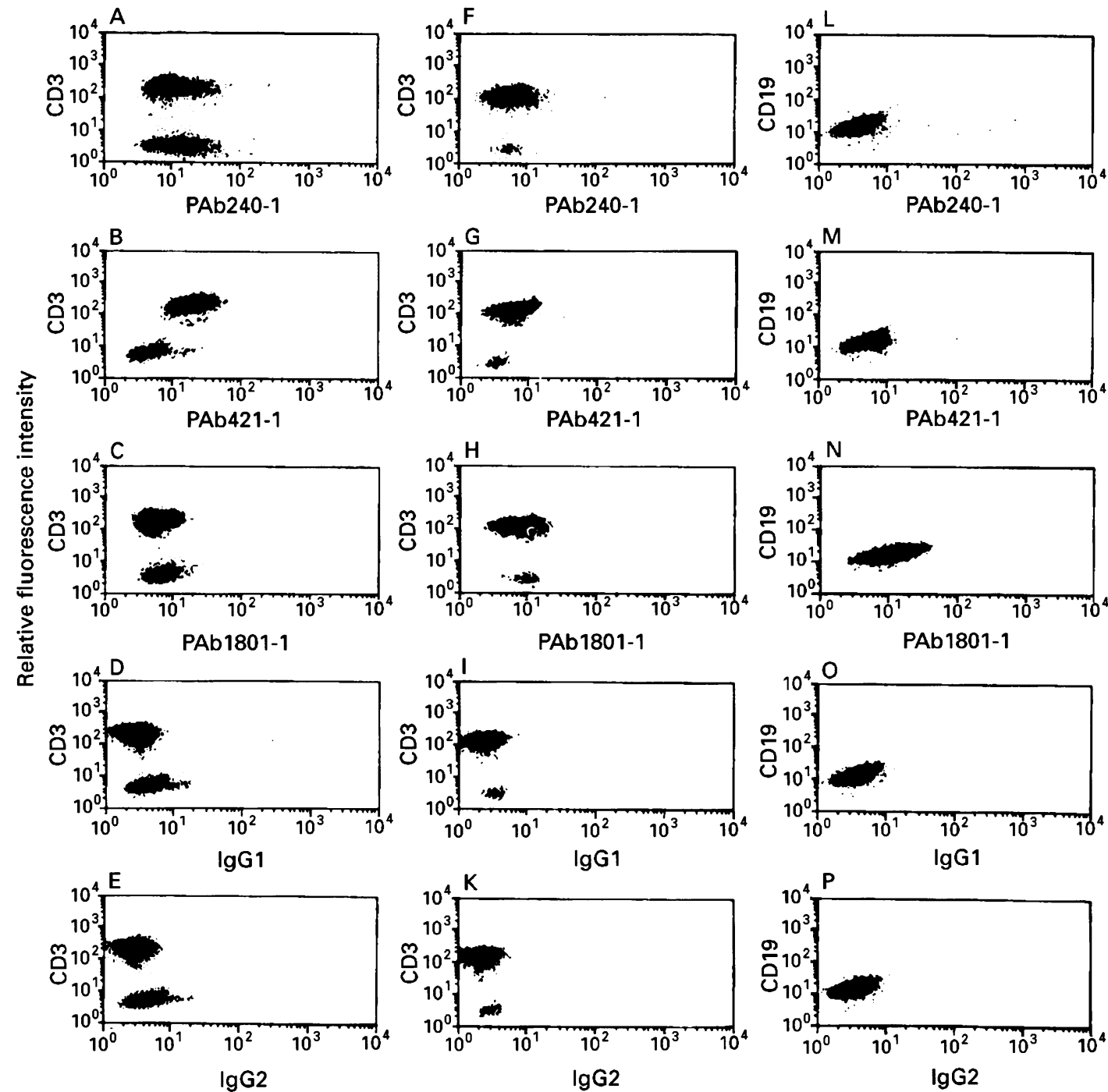

Relative fluorescence intensity

Figure 3 Binding of anti-p53 antibodies to peripheral $T$ lymphocytes of healthy controls (panels $A-E$ ), T-CLL lymphocytes (panels $F-K$ ), and B-CLL lymphocytes (panels $L-P$ ). The anti-p53 antibodies PAb240-1, PAb421-1, and PAb1801-1 bound to T lymphocytes, and PAb1801-1 bound to B-CLL lymphocytes.

juice in acute pancreatitis. ${ }^{45}$ In light of our results, all these reports on p53 expression in non-malignant cells must be questioned unless they are confirmed with additional antibodies and/or by other methods, such as western blotting.

Contamination of p53 specific antibody batches with antibodies reacting with antigens other than p53 should not occur with commercially available antibodies. However, such con-

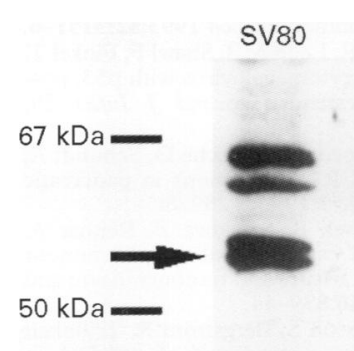

tamination cannot be excluded and it could be one explanation for the inconsistent results obtained with p53 specific antibodies in this study; it would also explain the crossreactivity of PAb421 with intermediate filaments discussed in another study. ${ }^{46}$

The validity of immunohistological analyses of $\mathrm{p} 53$ expression has been questioned before. ${ }^{47}$ The fact that the expression of p53 in rheumatoid synovial tissue could be confirmed using antibodies that were negative in immunohistochemical studies of the same tissue demonstrates that p53 can be detected in tissues by western blotting even when the immunohistological evaluation (using the same antibodies) does not demonstrate the presence of p53. It suggests that any demonstration of p53 in normal cells by immunohistology or flow cytometry should be confirmed, whenever possible, by western blot analysis, which was established as the gold standard for the demonstration of $\mathrm{p} 53$ expression in this study. All other results, especially those obtained with antibodies that show an unusual staining pattern in terms of the positive cells (for
Figure 4 Western blot analysis of synovial tissue extracts using PAb421-3. Lane 1, SV80 cells (positive control); lane 2, SAOS-2 cells (negative control); lanes 3-5, synovial tissue extracts (Syn 23, Syn 31, and Syn34) from three patients with rheumatoid arthritis. The positions of molecular weight markers and the p53 band are indicated. 
example, lymphocytes) or the positive subcellular compartment (for example, cytoplasmic staining), should be interpreted with the utmost caution, and should be considered for re-evaluation with bona fide anti-p53 antibodies.

The authors thank Professor J Heisel and Professor T Hopf (department of orthopaedics, University of Saarland) for providing with tissues from synovectomies. The work was sup ported by a grant from the BMFT (Bundesministerium fü Forschung und Technologie) and by Deutsche Krebshilfe W77 93/Mo2 to MM.

1 Götz C, Montenarh M. p53: DNA-damage, DNA repair and apoptosis. Rev Physiol Biochem Pharmacol 1995;127:65-95.

2 Montenarh M. Biochemical, immunological, and functional aspects of the growth-suppressor/oncoprotein p53. In Critical reviews in oncogenesis. Boca Raton: CRC Press. 1992:233-56.

3 Harris CC. The 1995 Walter Hubert lecture-Molecular epidemiology of human cancer: insights from the mutational analysis of the p53 tumour-suppressor gene. $B r f$ tional analysis of the

4 Moll UM, Riou G, Levine AJ. Two distinct mechanisms alter p53 in breast cancer: mutation and nuclear exclusion. Proc Natl Acad Sci USA 1992;89:7262-6.

5 Knippschild U, Oren M, Deppert W. Abrogation of wild-type p53 mediated growth-inhibition by nuclear exclusion. Oncogene 1996;12:1755-65.

6 Burk U, Selter H, Zwergel T, Wullich B, Montenarh M, Unteregger G. Different subcellular localization of wildtype and mutant p53 in prostate cancer cells. Int $\mathcal{F}$ Oncol 1995;7:1355-60.

7 Bartkova J, Bartek J, Vojtesek B, Lukas J, Rejthar A, Kovarik $\mathrm{J}$, et al. Immunochemical analysis of the p 53 oncoprotein in matched primary and metastatic human tumours. Eur $\mathcal{f}$ Cancer 1993;29A:881-6.

8 Barnes DM, Hanby AM, Gillett CE, Mohammed S, Hodgson S, Bobrow LG, et al. Abnormal expression of wild type p53 protein in normal cells of a cancer family patient. Lancet 1992;340:259-63.

9 Fritsche M, Haessler C, Brandner G. Induction of nuclear accumulation of the tumor-suppressor protein p53 by DNA-damaging agents. Oncogene 1993;8:307-18.

10 Voelkerding KV, Steffen DW, Zaidi SHE, Malter JS. Post-transcriptional regulation of the p53 tumor suppressor gene during growth-induction of human peripheral blood mononuclear cells. Oncogene 1995;10:515-21.

11 Osipovich OA, Misuno NI, Kolesnikova TS, Sudarikov AB, Voitenok NN. The difference in p53 antioncogene transcription in human monocytes and lymphocytes. Oncogene 1992; 7:549-52.

12 Pezzella F, Micklem K, Turley H, Pulford K, Jones M, Kocialkowski S, et al. Antibody for detecting p 53 protein by immunohistochemistry in normal tissues. $\mathcal{f}$ Clin Pathol 1994;47:592-6.

13 Villuendas R, Piris MA, Orradre JL, Mollejo M, Algara P Sanchez $\mathrm{L}$, et al. $\mathrm{p} 53$ protein expression in lymphomas and reactive lymphoid tissue. $\mathcal{F}$ Pathol 1992;166:235-41.

14 Mateo MS, Sanchez-Beato M, Martinez JC, Orfao A, Orradre JL, Piris MA, et al. p53, Rb and bcl-2 expression during the cell cycle: a study in phytohaemagglutinin stimulated lymphocytes and microwave irradiated lymphoid tissue sections. $₹$ Clin Pathol 1995;48:151-59.

15 Martinez JC, Mateo M, Sanchez-Beato M, Villuendas R Orradre JL, Algara P, et al. MDM2 expression in lymphoid cells and reactive and neoplastic lymphoid tissue. Comparative study with p53 expression. F Pathol 1995;177:2734.

16 Speir E, Modali R, Huang ES, Leon MB, Shawl F, Finkel T, et al. Potential role of human cytomegalovirus and $\mathrm{p} 53$ interaction in coronary restenosis. Science 1994;265:391-4.

17 Imatani A, Sasano H, Yabuki N, Kato K, Ohara S, Asaki S, et al. In situ analysis of tissue dynamics and p53 expression in human gastric mucosa. $\mathcal{F}$ Pathol 1996;179:39-42.

18 Spandau DF. Distinct conformations of p53 are observed a different stages of keratinocyte differentiation. Oncogene

19 Helander SD, Peters MS, Pittelkow MR. Expression of p53 protein in benign and malignant epidermal pathologic conprotein in benign and malignant epidermal path
ditions. $₹ \mathrm{Am}$ Acad Dermatol 1993;29:741-8.

20 Hall PA, McKee PH, Du P, Menage H, Dover R, Lane DP. High levels of p 53 protein in UV-irradiated normal human skin. Oncogene 1993;8:203-7.

21 Szekely L, Pokrovskaja K, Jiang WQ, Selivanova G, Löwbeer M, Ringertz N, et al. Resting B-cells, EBVinfected B-blasts and established lymphoblastoid cell lines differ in their Rb, p53 and EBNA-5 expression patterns. Oncogene 1995;10:1869-74

22 Bi S, Lanza F, Goldman JM. The involvement of "tumor suppressor" p53 in normal and chronic myelogenous leukemia hemopoiesis. Cancer Res 1994;54:582-6.
23 Kulju KS, Lehman JM. Increased p53 protein associated with aging in human diploid fibroblasts. Exp Cell Res 1995; 217:336-45.

24 Dameron KM, Volpert OV, Tainsky MA, Bouck N. Control of angiogenesis in fibroblasts by p53 regulation of thrombospondin-1. Science 1994;265:1582-4.

25 Burmester GR, Locher P, Koch B, Winchester RJ, Dimitriu-Bona A, Kalden JR, et al. The tissue architecture of synovial membranes in inflammatory and noninflammatory joint diseases. I. Rheumatol Int 1983;3:17381 .

26 Koch B, Locher P, Burmester GR, Mohr W, Kalden JR. The tissue architecture of synovial membranes in inflammatory and non-inflammatory joint diseases. II. Rheumatol Int 1984;4:79-85.

27 Fitzgerald O, Soden M, Yanni G, Robinson R, Bresnihan B. Morphometric analysis of blood vessels in synovial membranes obtained from clinically affected and unaffected knee joints of patients with rheumatoid arthritis. $A n n$ Rheum Dis 1991;50:792-6.

28 Lalor PA, Mapp PI, Hall PA, Revell PA. Proliferative activity of cells in the synovium as demonstrated by a monclonal antibody, Ki67. Rheumatol Int 1987;7:183-6.

29 Firestein GS, Yeo M, Zvaifler NJ. Apoptosis in rheumatoid arthritis synovium. $\mathcal{F}$ Clin Invest 1995;96:1631-8.

30 Negoescu A, Labat-Moleur F, Lorimier P, Lamarcq L, Guillermet C, Chambaz E, et al. F(ab) secondary antibodies: a general method for double immunolabeling with primary antisera from the same species. Efficiency control by chemiluminescence. $\mathcal{f}$ Histochem Cytochem 1994;42:433-37.

31 Eyler YL, Lantz LM, Lewis Jr AM. Flow cytometric detection of DNA tumor virus nuclear oncogene products in unfixed cells: saponin FACS of viral oncogene products. $f$ Virol Meth 1994;46:23-7.

32 Gannon JV, Greaves R, Iggo R, Lane DP. Activating mutations in $\mathrm{p} 53$ produce a common conformational effect. A monoclonal antibody specific for the mutant form. EMBO ₹ 1990;9:1595-602.

33 McLure KG, Lee PWK. A PAb240 ${ }^{+}$conformation of wild type p53 binds DNA. Oncogene 1996;13:1297-303

34 Harlow E, Crawford LV, Pim DC, Williamson NM. Monoclonal antibodies specific for the SV40 tumor antigens. $\mathcal{F}$ Virol 1981;39:861-9.

35 Banks L, Matlashewski G, Crawford LV. Isolation of human p53 specific monoclonal antibodies and their use in the studies of human p53 expression. Eur f Biochem 1986;159: 529-34.

36 Ball RK, Siegl B, Quellhorst S, Brandner G, Braun DG. Monoclonal antibodies against simian virus 40 nuclear large tumour antigen: epitope mapping, papova virus cross-reaction and cell surface staining. EMBO f 1984;3: 1485-91.

37 Milner JA, Cook A, Sheldon M. A new anti-p53 monoclonal antibody, previously reported to be directed against the large $T$ antigen of simian virus 40. Oncogene 1987;1:453-5.

38 Vojtesek B, Bartek J, Midgley CA, Lane DP. An immunochemical analysis of the human nuclear phosphoprotein p53. New monoclonal antibodies and epitope mapping using recombinant p53. F Immunol Methods 1992;151:23744.

39 Milner J. Different forms of p53 detected by monoclonal antibodies in non-dividing and dividing lymphocytes. Nature 1984;310:143-5.

40 Said JW, Barrera R, Shintaku IP, Nakamura H, Koeffler HP. Immunohistochemical analysis of p53 expression in malignant lymphomas. Am f Pathol 1992;141:1343-8.

41 Matsushima AY, Cesarman E, Chadburn A, Knowles DM Post-thymic $\mathrm{T}$ cell lymphomas frequently overexpress $\mathrm{p} 53$ protein but infrequently exhibit p53 gene mutations. Am $\mathcal{F}$ Pathol 1994;144:573-84.

42 Cesarman E, Inghirami G, Chadburn A, Knowles DM. High levels of $\mathrm{p} 53$ protein expression do not correlate with p53 gene mutations in anaplastic large cell lymphoma. $\mathrm{Am}$ f Pathol 1993;143:845-56.

43 Villuendas R, Piris MA, Algara $P$, Sanchez-Beato $M$, Sanchez-Verde L, Martinez JC, et al. The expression of p53 protein in non-Hodgkin's lymphomas is not always dependent on p53 gene mutations. Blood 1993;82:3151-6.

44 Speir E, Huang ES, Modali R, Leon MB, Shawl F, Finkel T, et al. Interaction of human cytomegalovirus with p53: possible role in coronary restenosis. Scand $\mathcal{f}$ Infect Dis 1995;99(Suppl): 78-81.

45 Kalthoff H, Schmiegel W, Roeder C, Kasche D, Schmidt A Lauer G, et al. p53 and K-RAS alterations in pancreatic epithelial cell lesions. Oncogene 1993;8:289-8.

46 Bartek J, Bartkova J, Vojtesek B, Staskova Z, Rejthar A, Kovarik J, et al. Patterns of expression of the p53 tumour suppressor in human breast tissues and tumours in situ and in vitro. Int $f$ Cancer 1990;46:839-44.

47 Strang P, Nordström B, Nilsson S, Bergström R, Tribukait B. Mutant p53 protein as a predictor of survival in endometrial carcinoma. Eur 7 Cancer 1996;32A:598-602. 